\title{
ROMA HAKSIZ REKABET HUKUKUNA İLISSTKIN OLARAK ACTIO SERVI CORRUPTI
}

\author{
Yrd. Doç. Dr. Gökçe Türkoğlu ÖZDEMIR*
}

\section{Giriş}

Roma ekonomik yapısına ilişkin Roma hukukunca getirilmiş olan yasal düzenlemeler, üzerinde çalışılması gereken bir alandır. Çünkü bu konuda yapılacak tespitler, günümüz hukuku ve ekonomik yapısına örnek oluşturabilecektir. Roma ekonomik yapısı hakkında oldukça fazla bilgiye sahip olmamıza rağmen, bu yapıya ilişkin yasal düzenlemelere ilişkin, elimize ulaşan kaynak sayısı son derece sınırlıdır. Bu yüzden ilgili konu hakkında bazı noktalarda kesin saptamalar yapabilmek tam anlamıla mümkün olmamaktadır.

Roma ekonomisini ve buna ilişkin yasal düzenlemeleri incelerken, doğal olarak, bunların uygulandığı zaman diliminin ve bu zaman dilimindeki ihtiyaçların göz önünde bulundurulması gerekir. $\mathrm{Bu}$ nedenle, Roma hukukunca yapılmış olan, ekonomiyi düzenlemeye yönelik yasal düzenlemelerin, günümüz hukukunda olduğu kadar karmaşık ya da pek çok alanı birlikte ilgilendirir biçimde olabileceğini düşünmek yanlış olacaktır. Ancak yine de, Roma hukukunun bu alanda da önemli adımlar attığını söylemek mümkündür.

$\mathrm{Bu}$ çalışmanın konusunu, işlerini kölelerine gördüren efendilerin, kölelerinin, efendilerin rakipleri tarafından kışkırtılarak, yoldan çıkarılmaları ve böylece efendilere ait ticarî sırları açığa çıkartılması durumunda, efendilerin korunmasını konu edinen davanın haksız rekabetin engellenmesi düşüncesinin kökeni olarak görülüp görülemeyeceği sorusunun yanıtlanmas1 oluşturmaktadır.

\footnotetext{
Dokuz Eylül Üniversitesi Hukuk Fakültesi Öğretim Üyesi
} 


\section{Genel Olarak}

Roma devletinin ekonomiye olan yaklaşımı, en basit şekilde liberalist bakış açısıyla açıklanabilirr ${ }^{1}$. Devletin, ekonomiye müdahalesi, Roma devletinin farklı dönemlerinde değişmekle birlikte, genellikle oldukça sınırlı idi $^{2}$. Hatta özellikle cumhuriyet ve ilk imparatorluk dönemlerinde, bu müdahale yok denecek kadar azken, ilk imparatorluk döneminin sonlarından itibaren artmışt1 $^{3}$. Buna göre, liberal ekonominin önemli bir unsuru olan serbest rekabet, Roma devletinin faaliyetlerinden büyük ölçüde etkilenmemişti. Aslında günümüz hukuku açısından çok büyük önemi bulunan haksız rekabet hukuku, esas olarak oldukça yakın tarihlidir. Doğal olarak bu hukuk dalının tam anlamıyla Roma hukukuna dayandırılabilmesi mümkün değildir ${ }^{4}$.

Schiller, A. A.: Roman Law, Mechanisms of Development Mouton, 1978, s. 125 (Roman Law); Provera, G.: "Visuali Romanistiche in Tema di Patti di non Concurrenza", Annali Camerino, V. 31, 1965, s. 223-51; Charlesworth, M. P.: TradeRoutes and Commerce of the Roman Empire, Hildesheim, 1961, s. 10 vd.; Jones, A. H. M.: The Later Roman Empire, 284, 602; A Social, Economic and Administrative Survey, V. I, Oxford, 1973, s. 25 vd. (Empire); Rostovtzeff, M.: The Social and Economic History of the Roman Empire, 2. ed., V. II, Oxford, 1957, s. 17 vd.

2 Wacke, A.: "Freedom of Contract and Restraint of Trade Clauses in Roman and Modern Law", Law and History Review, V. 11, No. 1, Spring 1993, s. 3; Esas olarak, tarım ürünlerinin ve ev eşyalarının üretiminde ve dağıtımında devlet tarafından, küçük esnafi korumak amaçlı olarak, büyük sermayeli kuruluşlara belli sınırlamalar konulması söz konusu idi. Bu yönde bir devlet kontrolünün iki temel amacı bulunmaktaydı: İlki, devlet hazinesine gelir sağlamak için gerekli olan kaynakları yaratmak ve bunların devamını sağlamak ve ikincisi de başkent olan Roma şehrinin nüfusunun ihtiyaçlarını karşılamak. Devletin masrafları, büyük ölçüde vergilerden, devletçe toplanan geçiş ücretlerinden ve devlete ait olan özellikle madencilik sektöründeki birkaç tekelden karşılanmaktaydı. Devletin görevleri arasında, halkın gıda ve erzaklarının sağlanması ve kişilere kendileri için uygun mesleklerin bulunması yer almaktaydı.

Tengström, E.: Bread for the People: Studies of the Corn Supply of Ancient Rome, Oxford, 1980, s. 40; Roma devleti, yollar, su kemerleri, tapınaklar, kaleler, şehir duvarları inşa ettirerek hem pek çok kişiye istihdam olanağı sağlamakta, hem de kamu hizmeti vermekteydi. Ayrıca Roma'da, vurgunculuğa ve özellikle, tahıl üzerinde yapılan olanına büyük cezalar getirilmiş olmakla birlikte, tam olarak engellendiği söylenemezdi.

3 Karadeniz, Ö.: Iustinianus Zamanına Kadar Roma'da İş İlişkileri, Ankara, 1972, s. 236 vd. (Iss); Frank, T.: An Economic Survey of Ancient Rome, New York, 1959, s. 50 vd. (Economic); Roma devletinin kurulmasından itibaren çok uzun bir süre boyunca, devletin ekonomik hayatta etkin bir rol oynamamasının sonucu olarak, iş ilişkilerini özel girişimler düzenlemişti. Daha sonra, ilerleyen dönemlerde, devletin bu alandaki faaliyetleri artınca, iș ilişkilerinin kamu hukuku alanında da düzenlenmesi söz konusu olmuş ve Klâsik sonrası hukuk döneminde esas olarak güdümlü ekonomi etkin olmuş, yani devletin etkisi daha yoğun şekilde hissedilir olmuştu.

4 De Martino, F.: Storia Economica di Roma Antica, V. I, Firenze, 1979, s. 48 vd.; Duncan-Jones, R.: The Economy of Roman Empire, 2. ed, Cambridge, 1982, s. 30; Finley, M. I.: The Ancient Economy, updated, California, 1999, s. 87 vd.; Heichelheim, F.: An Ancient Economic History, V-I, Leiden, 1958, s. 129. 
Günümüz de, işgücü dolaşımının çok artması, iş olanaklarının daha fazla ve çok çeşitli olması, teknik bilgi ve beceriye duyulan gereksinimin büyümesi, iş değiştirme sonucunda taraflar arasındaki güvenin devam etmesi ve uzun zaman boyunca meslekî eğitim alarak uzmanlaşmış kişilerin belli şekilde denetlenmesi gerekliliğini doğurmuştur. Oysa Roma Klâsik Hukuk Döneminde, diğer antik toplumlarda olduğu gibi, günümüzün tam aksine tekdüze, işgücünün çok az hareketli olduğu ve baskın biçimde tarıma dayanan ekonomik bir yap1 hüküm sürmekteydi. Buna bağlı olarak da, rekabet baskıs1, günümüzle kıyaslanamayacak kadar az oranda etkili olmaktaydı. Bu dönemlerde iş dünyası esas olarak, el üretimi yapan küçük işletmelerden oluşmaktaydı. İhracat da, taşımacılık masraflarının çok ağır olması nedeniyle, pek fazla yapılamamaktayd1 ${ }^{5}$. Ancak, "Roma hukukunda haksız rekabet hukukuna ilişkin hiçbir düzenleme yapılmamıştır" şeklindeki bir tespit de tam anlamiyla doğru olmaz ${ }^{6}$.

Örneğin eyalet yöneticilerinin, herkesin yasalara aykırı şekilde iş görmemesi hususunda özel dikkat göstermeleri gerekmekteydi. Bu şekilde hiç kimse haksız rekabette bulunmamış ya da haksız rekabetten ötürü zarar görmemiş olurdu. Aynı şekilde eyalet yöneticileri, bir kimsenin yasalara uygun şekilde ticarî faaliyette bulunurken cezalandırılmaması ve her çeşit tehditten korunmasını da güvence altına almaktaydılar. O halde, eyaletlerde yaşayanların yasal ticarî faaliyetlerinin korunması ve yasadışı ticarî faaliyetlerden etkilenmemelerini sağlamak, eyalet yöneticilerinin görevleri arasindayd ${ }^{7}$.

Şüphesiz, yöneticiler kendilerine tanınmış olan zorlayıcı yetkileri (coercitio $)^{8}$, bu alanda da kullanarak haksiz rekabeti engellemeye

Rostovtzeff, s. 30 vd.; Duncan-Jones, s. 46 vd.; Jones, A. H. M.: The Roman Economy, Studies in Ancient Economics and Administrative History, Oxford, 1974 (History).

6 Schechter, F. I.: The Historical Foundation of the Law Relating to Trade-Marks, New York, 1925, s. 5 vd.; Hatta haksız rekabet hukukununda önemli bir yeri olan markalar hukukunun dayanağının Roma hukuku olduğu düşünülmektedir.

7 Stein, P.: Regulae Iuris, from Juristic Rules to Legal Maxims, Edinburgh, 1966, s. 44 vd., Ruggiero, C. P.: Stato Civile ed il Diritto Internazionale Privato, Padova, 1992, s. 125; Eyalet yöneticilerinin görevleri arasında, kişilerin meslekî faaliyetlerde bulunma özgürlüğünün korunması gelmekle birlikte, Roma hukukunun günümüzde olduğu gibi, bu konuda faaliyet gösterecek, denetleyeci nitelikte, devlete bağlı, özel bir birimin ya da en azından özel bir görevlinin tahsis edildiği sonucuna varamayız (D. 1, 18, 6, 4). Aslında Roma hukukuna göre, devlet tarafından görevlendirilmiş olan eyalet yöneticilerinin oldukça fazla görevleri ve geniş yetkileri bulunmaktaydi. Ama bu yetkiler arasında yer alan haksız rekabeti engelleme yönündeki görevleri ise, fazlaca ses getirmiş olan yetkileri arasında değildi.

Karadeniz, Isş, s. 235; İş ilişkilerini yönetmek ve denetlemekle görevlendirilmiş bazı magistra'lar bulunmaktayd.

8 De Zulueta, F.: The Institutes of Gaius, P. II, Oxford, 1953, s. 248. 
çalışıyorlardı. Roma hukukunda, özellikle Klâsik hukuk döneminde, bu şekildeki zorlayıcı yetkiler doğrultusunda, haksız rekabeti önleyecek genel bir dava yerine, ortaya konan şikayetlere karşılık olarak dağınık halde (ad hoc) davalar karşımıza çıkmaktayd ${ }^{9}$.

Yöneticiler, esas olarak kendi önüne gelen her bir olayın özünü dikkate alarak, verilmesi gereken en doğru kararı vermeye çalışır; hukuka uygun olan davranışları teşvik edip, hukuka aykırı davranışları da, cezalandırırlard $1^{10}$. Bu şekilde düşünüldüğünde, eyalet yöneticilerine, bu çeşit sözleşmelere bağlanmış olan ve genellikle de uygulama da etkili olmayan, sözleşmenin geçersiz olacağ 1 yönündeki özel hukuk kuralının yanında, zorlayıcı nitelikteki kamu hukuku kuralı getirebilme yetkisi tanınmıştır denilebilir ${ }^{11}$.

Roma hukukunda, özellikle Klâsik hukuk döneminde haksız rekabetin önlenmesi için getirilmiş olan yasal düzenlemeler iki temel noktaya dayanmaktaydılar: bunlardan ilki, haksiz rekabette bulunduğu iddia edilen kişinin ticarî faaliyetlerde bulunması, ancak bu yöndeki bir mahkeme kararıyla durdurulabilirdi. İkincisi de, ancak çok ender durumlarda, örneğin şans oyunları, büyücülük, kehanetlerde bulunma gibi bazı ticarî faaliyetler, kamu yararı gerekçesiyle durdurulabilir ve yapılmaları yasaklanabilirdi. Aşağı sınıf olarak kabul edilen bazı meslekler, örneğin oyunculuk, özgür kişilerce yapılan gladyatörlük (auctorati) $)^{12}$, kural olarak yasaklanmamıştı.

9 Schulz, F.: Classical Roman Law, Reprint of the Ed. 1951, Enlarged by a Preface Scientia, Aalen, 1992, s. 24-5; Daube, D.: Forms of Legislation, Oxford, 1956, s. 25; De Zulueta, s. 222 vd.; Pacchioni, G.: Corso di Diritto Romano, 2. V., Torino, 1910, s. 857 vd.; Costa, E.: Storia delle Fonti del Diritto Romano, Torino 1909, s. 549; Zaten Roma hukukunun belirleyici karakterlerinden biri de, Roma hukukçularının teorikten çok uygulamaya yönelmiş olmalarından ötürü, genel nitelikte bir dava kavramının bulunmamasıdır. Buna bağlı olarak, Roma hukukunda, her bir hakka bağlı olarak, farklı davalar tanınmıştı. Actio denilen dava kavramı, Roma hukukunda hakların ortaya çıkması, gelişmesi ve korunmasında çok önemli bir rol oynamıştı. Buna göre, hakkının çiğnendiğine inanan kişi, adlî makamlara başvurarak, hukuk kurallarına aykırı davranışı ispat ederse, davalının, Roma hukukunca düzenlenmiş olan ilgili yaptırımlara maruz kalması söz konusu olmaktaydı.

10 Wacke, s. 5; O halde, eyalet yöneticilerinin kısaca kişilerin ticarî faaliyetleri sırasında yasalara uymalarını güvence altına aldıklarını söyleyebiliriz. Ayrıca bu kişiler, oldukça çok kullanılan, contro bonos mores biçiminde sözleşme yapılmasını da engellemekteydiler.

11 Schiller, s. 216.

12 Umur, Z.: Roma Hukuku Lügatı, s. 26 (Lügat); Bir ücret karşı1lığında, tehlikeli sirk oyunlarına katılmak için faaliyetini bir müteşebbise bağlayan kimseye auctoratus denilmekteydi. Bu durumdaki kimseler, özgür Roma vatandaşı statüsünde kalmaya devam etmekle birlikte, birçok açıdan ehliyetleri kıstlanmış olup, bir de şerefsiz durumuna düşerlerdi. 
Ancak bu çeşit faaliyetleri görmek, söz konusu kişileri şerefsiz (infamis) $)^{13}$ olarak damgalamak için yeterli kabul ediliyordu. Bu yüzden, pek az kimse bu meslekleri yapmaya cesaret edebiliyordu. Ancak bunlar istisna niteliğinde idi $^{14}$.

\section{Actio Servi Corrupti'nin Tanımı}

Roma'da işçi sınıfı, hür, azatlı ve kölelerden oluşturmaktaydı. Klâsik hukuk döneminde, bu sınıfın en büyük kısmını köleler oluşturmaktaydı. Roma ekonomisinde çalışması ve üretime yön vermesi açısından köle ve azatlılar etkin sınıfı oluşturuyordu. Özgürler arasındaki iş ilişkileri oldukça sınırlı şekilde idi ${ }^{15}$. Azatlılar, her ne kadar onları azat etmiş olan efendilere karşı bazı yükümlülükler taşımaya devam etseler de, kendi iradeleri ile hareket etmekteydiler. Oysa köleler açısından böyle bir durum söz konusu olmamaktaydı. İş hayatında çeşitli yetkiler tanınan köleler efendilerine ait

13 Karadeniz-Çelebican, Ö.: Roma Hukuku, Tarihi Giriş- Kaynaklar- Genel KavramlarKişiler Hukuku- Hakların Korunması, Yeni Medeni Kanun'a Uyarlanmış 8. basım, Ankara, 2003, s. 166 (Roma Hukuku); Di Marzo, S. (Çev. Umur): Roma Hukuku, 5. Bas1, İstanbul, 1954, s. 52; Greenidge, A. H. J.: Infamia, Its Place in Roman Public and Private Law, Oxford 1894, s. 10 vd.; Schulz, s. 45; Şerefsizlik bir kişinin toplumdaki saygınlığını yitirmesi anlamına gelirdi. Roma hukukuna göre, şerefsiz ilan edilen kişiler, kamu hizmetlerinden yoksun bırakılırlar, seçme ve seçilme gibi haklarını yitirirlerdi. Uygunsuz davranışları dolayısıyla ordudan kovulmuş asker ve kumandanlar, tiyatro oyuncuları, fena meslek sahipleri, gladyatörler, kamu ya da özel suçlardan veya şirket, vesayet, vekâlet, vedia, inançlı sözleşmelere aykırı davranmaktan ötürü mahkum olanlar, müsrifler, kocasının ölümünden sonra bir sene beklemeden evlenen kadınlar ve bunlarla evlenen erkekler ve bu evliliğe rıza gösteren aile babaları, aynı zamanda iki defa nişanlanan veya evlenenler, şerefsiz sayılırlardı. Şerefsizliğin çeşitli şekilleri vardı. Şerefsizler, tanık olamazlar, onlara vasiyetnamelerinde mal vasiyet eden kişilerin, vasiyetnamelerine itiraz edilebilirdi.

\section{Wacke, s. 6.}

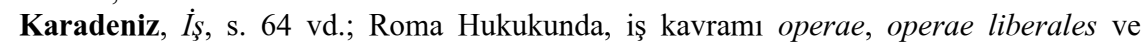
operae illeberalis şeklinde bir ayırıma tâbi tutulmaktaydı. En basit anlatımıyla, operae liberalis denilen hizmetler, yüksek hizmetler, operae illeberalis ise aşağı hizmetler anlamına gelmekteydi. Böyle bir ayırım bulunmakla, birlikte hangi işlerin operae liberalis hangilerinin ise, operae illeberalis olduğuna dair kesin bir liste bulunmamaktaydı. Operae liberalis sayılan yüksek hizmetler, genellikle fikrî çalışmalar olarak kabul edilmekteydi. Bunların ücret karşılığında yapılması hoş karşılanmamaktaydı. Ancak, sistem dışı yargılamanın konsu olabilecek özel bir ücret çeşidi olan şeref ücreti (honorarium) karşıllğında yapılması mümkün olabilirdi. Operae liberalis ise, çoğunlukla bedenî hizmetlerdi ve bunların ücret karşılığında gerçekleştirilmesi hoş karşılanırdı. Aslında böyle bir ayırım, Roma'da egemen olan ekonomik, siyasî, dinî ve ahlakî görüşlerle sıkı sıkıya bağlı idi.

Karadeniz, $\dot{I}_{S ̧}$, s. 16 vd.; Roma'da özellikle ilk dönemlerde, kol gücüne dayanarak yapılan işler küçük görüldüğünden, bunların özgür kişiler tarafından yapılması pek hoş karşılanmamaktaydı. Yine, bir işin ücret karşılığında görülmesine de, Roma'da iyi gözle bakılmamaktaydı. Bu yüzden özgürler arasındaki iş ilişkileri Roma'da çok gelişmemişti. Ancak, bu durum, kol gücüne dayanarak çalışmak zorunda kalan fakir Romalıların bulunmadığı anlamına gelmemekteydi. 
işleri yönetiyorlar ve bu yolla ekonomik yapıyı önemli ölçüde etkiliyorlard1 ${ }^{16}$. Bu bağlamda, Roma toplumunun çalışan kesimi olmaları nedeniyle, Roma haksız rekabet hukuku açısından kölelerin davranışlarının önemi yadsınamazd1. Biz bu çalışmada, actio servi corrupti'yi kölenin efendisinin işlerini görürken, haksız davranışlarda bulunarak, onu zarara sokması durumunu esas alarak, haksız rekabet hukuku boyutu ile inceleyeceğiz.

Actio servi corrupti ya da actio de servo corrupto denilen bu dava, kısaca ahlakı bozdurulan köleye ilişkin dava şeklinde tanımlanabilir ${ }^{17}$. Bu şekilde, köleye kasten yapılan fiziksel, aklî ya da ahlakî kötüleştirmeler sonucunda, kölenin değeri azalmaktayd ${ }^{18}$.

Iust. Inst. 4, 6, 23: "In duplum agimus veluti furti nec manifesti, damni iniuriae ex lege Aquilia, depositi ex quibusdam casibus: item servi corrupti, quae competit in eum, cuius hortatu consiliove servus alienus fugerit aut contumax adversus dominum factus est aut luxuriose vivere coeperit aut denique quolibet modo deterior factus sit (in qua actione etiam earum rerum), quas fugiendo servus abstulit, aestimatio deducitur.

Suçüstü olmayan hırsızlıktan, Lex Aquilia ${ }^{19}$ çerçevesinde mala verilen

16 Buckland, W. W.: Roman Law of Slavery, the Condition of the Slave in Private Law from Augustus to Justinian, Cambridge, 1908, s. 98 vd. (Slavery); Iust. Inst. 2, 9, 3'de belirtildiği üzere, köleler tarafından görülen işlerden elde edilen kârlar, doğrudan efendiye ait olurdu.

Karadeniz-Çelebican, Roma Hukuku, s. 129 vd.; Roma Hukukunda bir kişinin hukuken kişi sayılabilmesi, yani hak ehliyetine sahip olabilmesi için, üç şart aranmaktaydı. Bunlardan ilki, status libertatis denilen özgürlük durumu idi. Roma Hukukunda ancak özgür olanlar, hak ehliyetine sahip olmaktaydı. İkinci şart, status civitatis denilen vatandaşlık durumu idi. Hak ehliyetine sahip olmak için, özgür olmanın yanısıra, bir de Roma vatandaşı olma şartı aranmaktaydı. Üçüncü şart da, status familiae denilen aile durumu idi. İlk iki şarıtı gerçekleştirenlerin, hak ehliyeti sahibi olabilmeleri için bir de aile babasının hakimiyeti altında olmamaları gerekmekteydi. Köleler, özgür olma şartını sağlayamadıklarından dolayı, hak ehliyeti sahibi olamazlar, buna bağlı olarak da, kendi adlarına hak sahibi olamaz ve borç altına giremezlerdi.

17 Umur, Lügat, s. 6.

18 Buckland, W. W.: A Text-Book of Roman Law from Augustus to Justinian, 2. Ed., 1932, Cambridge, s. 63 (Text-Book).

19 Rado, T.: Roma Hukuku Dersleri, Borçlar Hukuku, İstanbul, 2001, s. 194; Umur, Lügat, s. 113; lex aquilia, M.Ö. 287 yılında Aquilius tarafından çıkarılan bir kanun olup, bu kanun ile başkasının malına haksız olarak verilen zararların tazmin edilmesi amaçlanmıştı. Buna göre, başkasına ait köle ya da sürü hayvanı, hukuka aykırı olarak öldürülürse, malın malik nazarındaki değeri de gözönünde bulundurularak, köle ya da hayvanın olaydan önceki son senede ulaşmış olduğu en yüksek değeri ödenirdi. Başkasına ait bir mala hukuka aykırı şekilde zarar verilirse, malın son ay içinde ulaştığı en yüksek değeri ödenirdi. Önceleri bu kanun hükümlerinin uygulanabilmesi için, mala ya da köle ile hayvana maddi bir temasta bulunulması sonucunda zarar verilmesi gerektiği kabul ediliyordu. Iustinianus zamanında ise, uygulamanın kapsamı genişletilerek, maddî temas şartı aranmaz hale gelmişti. 
zarardan, bazı durumlarda vediadan dolayı iki misli için dava ederiz; Örneğin tavsiye ve teşvik ile başka birisine ait kölenin kaçmasına, malikine karşı isyan etmesine, ahlaksız bir hayat yaşamaya başlamasına veya herhangi bir şekilde daha kötü bir hale gelmesine neden olmuş kimseye karşı açılan servi corrupti (köleyi yoldan çıkarma) davası da bu yönde bir davadır. Bu davada, kölenin kaçarken beraberinde götürdüğü şeylerin zararı da, takdir yoluyla belirlenir: yine yukarıda söylediğimiz gibi, belirli mal olarak kutsal yerlere vasiyet edilmiş mallar için de, aynı şekilde dava ikame edilir".

Ius. Inst. 4, 6, 26: "Sed furti quidem nec manifesti actio et servi corrupti a ceteris, de quibus simul locati sumus, eo differt, quod hae actiones omnimodo dupli sunt: at illae, id est damni iniuriae ex lege Aquilia et interdum depositi, infitiatione duplicantur, in confitentem autem in simplum dantur: sed illa, quae de his competit, quae relicta venerabilibus locis sunt, non solum infitiatione duplicatur, sed et si distulerit relicti solutionem, usque quo iussu magistratuum conveniatur solventem simpli redditur.

Fakat suçüstü olmayan hırsılılı davası ve yoldan çıkarılmış köleye ilişkin dava ile, sözünü ettiğimiz diğer davalar arasında şu fark vardır ki, bunlar her zaman iki katına mahkumiyete dair oldukları halde, diğerleri, yani lex Aquilia çerçevesinde mala verilen zarar davası ile bazen vedia davası, yalnız davalının inkarı durumunda davalı, zararın iki katına mahkum edilir. İtiraf halinde ise, bir misline mahkum edilir. Oysa kutsal yerlere vasiyet edilmiş mallara ilişkin ve burada söz edilmiş davada, yalnız inkar durumunda değil, vasiyet edilmiş şeyin verilmesini magistra'larımızın ${ }^{20}$ emrine kadar geciktirmiş olanlara da iki misli mahkumiyet yüklenir; magistra'ların emrinden önce itiraf edilerek verilmesi durumunda ise, bir misli oranında dava edilirler".

\section{Actio Servi Corrupti' nin Konusu}

Haksız rekabet hukuku açısından önem taşıması bakımından, actio servi corrupti nin konusunu esas olarak, başkasına ait bir kölenin, fena tavsiyelerle yoldan çıkarılarak, kölede gerçekleşen değer kaybının ve efendinin uğramış olduğu zararın iki mislinin ödenmesi oluşturmaktaydı ${ }^{21}$. Roma'da, özellikle Klâsik hukuk döneminden itibaren işçilerin iş ilişkisi sona erdikten sonra işçinin, işverene sadık kalması ve onun meslekî sırlarını

20 Villey, M. (Çev. Tahiroğlu, B.): Roma Hukuku Güncelliği, 7. Bası, İstanbul 2000, s. 23; Magistra, Romanın çeşitli dönemlerinde, devletin başında bulunan büyük devlet adamlarına verilen isimdir. Özellikle, krallık, cumhuriyet ve ilk impatarluk - Principatus dönemlerinde, devletin yönetiminde bulunan üç büyük organdan bir tanesi, magistratus idi.

21 Umur, Lügat, s. 6. 
saklanması gerekliliği bilinmekteydi ${ }^{22} . \mathrm{Bu}$ gerekliliğin hukuken güvence altına alınması çeşitli durumlarda, praetor' $\operatorname{lar}^{23}$ tarafından tanınmış olan actio servi corrupti ile sağlanmaktaydı.

Actio servi corrupti'yi, konusuna ilişkin örnekler vererek açıklamak istersek; işveren konumundaki efendinin, işçi konumundaki kölesi, kötüniyetli bir üçüncü kişi tarafından kandırılarak, efendiye ait meslekî sırları açıklatılmış ya da, kandırılarak yoldan çıkarılmış köle, efendisinin meslekî faaliyetlerine ilişkin planlarını, müşteri listelerini, belgelerini ve benzeri dokümanlarını çalıp, efendinin rakibine teslim etmiş ya da efendisinin rakibinin direktifleri doğrultusunda hareket eden köle, efendisinin ticarî dokümanlarını yok etmiş ya da bunları değiştirmişse, kölenin bu ve benzeri davranışlarından zarar gören efendi, kölesini bu şekilde davranmaya yönelten kötüniyetli rakibine karşı, actio sevi corrupti' yi açabilirdi ${ }^{24}$.

Efendi, söz konusu davayı aleyhine olacak şekilde yönelteceği davalının kim olduğunu, bizzat kandırılan köleden, ya da herhangi bir şekilde kendiliğinden öğrenmiş olabilirdi. Actio servi corrupti ile efendiye, kölesini, kendi aleyhine davranışlarda bulunmak ve böylece onun ticarî işlerine zarar vermek için ayartan üçüncü kişilerden, kölenin bu davranışlarından dolayı uğradığ1 zararların tazminini isteme olanağı sağlanmaktayd ${ }^{25}$.

Actio servi corrupti'ye ilişkin Klâsik dönemin hukukçuları tarafından yapılan açıklamalar, ne yazık ki bu davayı tam olarak ortaya koymaya elverişli değildir ${ }^{26}$. Ancak, elimizdeki kaynaklardan edinilen bilgiler doğrultusunda, söz konusu davanın kullanılabileceği durumları iki grupta toplamak mümkündür. İlk grupta davacı konumundaki üçüncü kişi, aktif

22 Rostovtsev, s. 65 vd.; Barrow, R. H.: Slavery in the Roman Empire, 1928, s. 11 vd. (Slave); Bu dönemler, Roma devletinin ekonomik ve ticarî faaliyetlerinin arttığ 1 ve gelişme kaydettiği zamanlara denk gelmekteydi. Bununla bağlantılı olarak, Roma hukukunda haksız rekabete ilişkin örneklere, özellikle Cumhuriyet döneminin sonları ve ilk imparatorluk döneminin başlarından itibaren rastlanılmaktaydı.

23 Villey, s. 16; Praetor, devlet iktidarını kullanabilme, emrindeki personele emir verebilme ve bu emirlerin uygulanması için gerekli önlemleri alabilme yetkisine (imperium) sahip bir devlet adamıdır, yani bir çeşit magistra'dır.

24 Schiller, A. A.: "Trade Secrets and the Roman Law; The Actio Servi Corrupti", Colombia Law Review, V. 30, 1930, s. 838 (Trade).

25 Buckland, Slavery, s. 33 vd.; Roby, H. J.: Roman Private Law in the Times of Cicero and of the Antonines, V. I, Cambridge, 1902, s. $218 \mathrm{vd}$.

26 Schiller, Trade, s. 838; Barrow, Slave, s. 12. 
durumda, ikincisinde ise yalnızca kışkırtıcı, ön ayak olucu durumundaydı. İlk gruba girenlere verilebilecek örnekler arasında, ususfructus ${ }^{27}$ şeklinde kendisine verilmiş bir köleye işkence edilmesi ${ }^{28}$, ancilla $^{29}$ denilen dişi kölenin kaçırılması ve dövülmesi ${ }^{30}$, bir başkasına ait köleyi kalitesiz

27 Küçükgüngör, E.: Roma Hukukunda intifa hakk1 (ususfructus), Ankara, 1998, s. 21 vd.; Karagöz-Çokyaşar, H.: İntifa Hakkının Roma Hukukundaki Gelişimi ve Türk Hukukuna Etkisi, İstanbul, 2003, s. 30 vd.; Roma hukukunda ususfructus intifa hakkı anlamına gelmektedir. D. 7, 1, 1; İntifa hakkı, özünü korumak şartıyla başkasına ait malı kullanma ve semerelerinden yararlanma hakkıdır.

28 D. 7, 1, 66; Schiller, Trade, 839; Burada, actio servi corrupti ile aynı zamanda, actio legis Aquilia ve actio iniurarum'u da açabilmek mümkün olabilmekteydi, çünkü ortada hem fiziksel hasar hem de değer kaybı söz konusuydu. Rado, s. 194; Umur, Lügat, s. 9; Actio legis Aquilia, lex aquilia davası anlamına gelmekteydi. Bu dava praetor davası niteliğini taşımaktaydı. Önceleri yalnızca köle ya da hayvanlara, daha ilerleyen zamanlarda ise, her türlü mala damnum iniuria datum șeklinde verilen zararlardan dolay1, mal sahibinin uğramış olduğu zararların tazmin edilmesi amaçlanmaktaydı. Rado, s. 197 vd.; Umur, Lügat, s. 8; actio iniurarum ise, şahsiyete karş1 yapılan her çeşit tecavüzden doğan zararların tazmin edilmesi amacıyla açılan davaya denilmekteydi (Gai. 4, 182; I. 4, 16, 2). Actio iniuriaum, tam bir ceza davası niteliğinde iken, Iustinianus Döneminde, zararı da kapsaması nedeniyle, bu özelliğini yitirmiştir. Önceleri praetor, çeşitli iniuria suçlarını işleyenlerin ödemeleri gereken diyeti belirleyerek, zarar görene bu bedelin ödenmesini sağlamıştır. Örneğin, hafif tecavüzler için 25 As ödenmesi yerine, yeni iniuria çeşitleri yaratmayı tercih etmiştir. Maddî olarak kişiye karşı işlenmiş olan haksız fiillerin para cezasının ölçüsü, hakimin takdirine bırakılmıştır. Bu çeşit actio iniuriarum'a, actio iniuriarum aestimatoria yani, takdir edilmiş iniuria davası denilir. De convicio -hakaret etme, de ademptata pudicita -genç bir kızın ya da erkeğin namusuna ya da şerefine karşı işlenen haksız fiiler, ne quid infamandi causa fiat-şeref ve şöhrete zarar veren haksız fiiller ve iniuriis quae servis fiunt -kölesine kötü davranarak, efendisini küçük düşürmek, şeklinde yeni iniuria suçları ve bunlara ilişkin davalar yaratılmıştır. Genellikle uğranılan zararın takdirini, yani aestimatio'sunu davacı yapar. Hakim, davacıyı haklı bulursa, davalıyı, ya aynı miktara ya da daha azına mahkum eder. Ancak, işlenen haksız fiil ağırsa, bunun değerini praetor takdir eder. Aestimatio'su praetor tarafından yapılmış bir davayı gören hakim, dava sonunda davalıyı praetor'un takdir ettiği miktardan daha azına mahkum etmeye yetkili olmakla birlikte, praetor'un otoritesine duyulan saygı gereğince, bu yetkisini kullanmaz (Gai. 3, 224).

29 Carcopino, J.: Daily Life in Ancient Rome, the People and the City at the Height of the Empire, Trans. from French by Lorimer, London, 1941, s. 8; Roma Hukukunda genel olarak köle servi anlamına gelmekteydi. Ancak, kadın köleye serva ya da ancilla da denilmekteydi.

30 D. 47, 1, 2, 5; Schiller, Trade, s. 840; Burada, actio servi corrupti ile aynı zamanda, actio furti'nin açılabilmesi mümkün olabilmekteydi, çünkü fiziksel ve aklî hasar söz konusuydu. Buckland, W. W.: Elementary Principles of the Roman Private Law, Cambridge, 1912, s. 328 (Elementary); Actio furti, Roma hukukunda hırsızlık suçunu işlediği iddia edilen kişilere karşı açılan ceza davası idi. Roma toplumunda, hırsızlık şiddetle cezalandırılması gereken bir suç olarak kabul edildiğinden, ceza davası niteliğindeki actio furti ile aynı anda, yukarıda değinildiği üzere actio servi corrupti, tazminat davası, istihkak davası gibi duruma uygun diğer davalar da açılabilirdi. Aytıca actio furti, suç ortaklarına, malı saklayanlara karşı da açılabilirdi. 
meyhanelere götürmek ya da onunla kumar oynamak gösterilebilirdi ${ }^{31}$. O halde üçüncü kişi bu ve benzeri davranışlarından actio servi corrupti ile sorumlu tutulur ve dava sonunda haksız bulunursa, efendinin uğradığ 1 zararların iki mislini para ceza olarak ödemeye mahkum edilirdi ${ }^{32}$.

İkinci gruba, üçüncü kişinin başkasına ait köleyi kışkıtmasından kaynaklanan durumlar girmekteydi. Bunları da beşli bir sınıflandırmaya tâbi tutmak mümkündü; İlk olarak, başkasına ait kölenin üçüncü kişinin teşviki üzerine kaçmasi ${ }^{33}$, hırsızlık yapmas ${ }^{34}$, iniuria işlemesi ${ }^{35}$ ya da stuprum ${ }^{36}$ biçiminde ilişkiye girmesi ${ }^{37}$ durumunda köleyi bunlara teşvik eden üçüncü kişiye karşı actio servi corrupti açılabilirdi. İkinci olarak, köleye çatıya çıkmasına ya da su kuyusuna inmesine teşvik etme gibi, ona fiziksel bir zarar verme riskinin bulunduğu durumlar düzenlenmişti ${ }^{38}$. Üçüncüsü, köleye

31 D. 47, 10, 26; Bu metin esas olarak iniuria hakkında düzenlemeler yapmaktadır. Tahiroğlu, B.: Roma Hukukunda Iniuria, İstanbul, 1969, s. 4 vd. (iniuria); Umur, Z.: Roma Hukuku Ders Notları, 3. Bask1, İstanbul, 1999, s. 395 vd. (Notlar); Iniuria, şahsa ve şahsiyete verilen zarar demekti ve ius civile'nin tanıdığ 1 dört haksız fiil tiplerinden biriydi. Hukuka aykırı olarak yapılmış her fiil, iniuria kapsamına girmekteydi. Oniki Levha Kanunu zamanında iniuria, sadece bir kişinin fizik varlığına yapılan maddî tecavüz anlamında kullanılmıştı. Buna göre, genellikle, kısas biçiminde ceza veriliyordu. Ancak, taraflar anlaşırsa, aralarında bir diyet ödenmesi de mümkün olabiliyordu. Örneğn, bir uzvun kırılması durumunda (membrum ruptum), para anlaşması yapılmazsa kısas (talio) uygulanırdı. Ağır iniuria (iniuria atrox) durumunda ise, cezanın en üst sınırı, ilgili

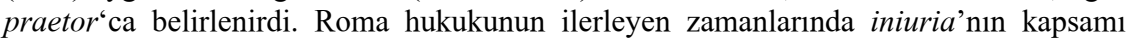
genişleyerek, buna maddi tecavüzlerin yanı sıra, kişiliğe, onura yapılan manevi saldırılar (contumelia) da dahil olmuştu. Yani yaralama ve dövmenin yanısıra, hakaret edilmesi de, iniuria'nın kapsamına alınmıştı.

32 Schiller, Trade, s. 840.

33 D. 11, 3, 1, 5; D. 47, 2, 36 pr.; Iust. Inst. 4, 18; D. 48, 15; Burada kıyaslama yapılarak dahi bir hırsızlı suçunun bulunduğu ve actio furti ${ }^{6}$ nin açılabileceği kabul edilmez. Buckland, Slavery, s. 31; Ancak böyle bir durumda, üçüncü kişiye karşı Lex Fabia de Plagiariis kapsamında bir ceza davası da açılabilirdi. Lex Fabia de Plagiariis denilen kanunla, bir Roma vatandaşını, bir azatlıyı veya başkasına ait bir köleyi zorla satan ya da satın alan kimse ve başkasının kölesini, efendisinden kaçmaya ikna eden kişi, ellibin sesters ödeme şeklindeki ağır cezaya mahkum ediliyordu. M.Ö. II. yüzyılın başlarında bu suçun cezası idam olarak kabul edilmişti.

34 D. 11, 3, 1, 5; D. 11, 3, 11, 2, Bu durumda hem actio furti, hem de actio servi corrupti açılabilirdi.

35 D. 11, 3, 1, 5 .

36 Umur, Lügat, s. 201; Stuprum, evlenmemiş ya da dul kadınla, bir erkeğin belirli bir süre için beraber yaşamaları anlamına gelmekteydi. Bu çeşit birlikteliklerde, çiftlerin sürekli olarak beraber yaşama niyeti anlamına gelen affectio maritalis bulunmadığından, ortada bir evliliğin bulunduğu söylenemezdi. Evli bir kadının başka bir erkekle ilişkisi demek olan adulterium da, stuprum'dan farklı idi.

D. 11, 3, 2 .

38 MacCormack, G.: "The Liability of Mandatary", Labeo 18, 1972, s. 163; D. 11, 3, 3, 1; Bunun gibi durumlarda actio servi corrupti'nin yanı sıra actio legis Aquiliae'yı açmak da mümkündü. 
ahlakî hataya düşmesi yolunda yapılan teşviklerdi. Bunlara örnek olarak kölenin pekçok kişiyle aşk hayatı yaşamas ${ }^{39}$, kumar oynaması ${ }^{40}$, ayaklanmalara katılması ${ }^{41}$, sihir ve büyü ile uğraşmass ${ }^{42}$, lüks içinde yaşamas ${ }^{43}$ ve benzeri şekilde bir başka köleyi yanlış biçimde davranmaya ikna etmesi ${ }^{44}$ verilebilirdi. Dördüncüsü, kölenin efendisine manevî zarar vermesi yönünde üçüncü kişi tarafından teşvik edilmesiydi. Buna göre, kölenin efendisine isyan etmesini ${ }^{45}$ veya efendisini aşağılayarak ona karşı çıkmasını ${ }^{46}$ teşvik eden üçüncü kişiye karşı actio servi corrupti açılabilirdi. Ayrıca, yine köle, bir üçüncü kişinin onu yoldan çıkarması üzerine, efendisinin kendisine acımasızca davrandığını iddia ederek, yöneticilere onu şikayet edip, halk önünde efendisini küçük düşürmüşse, üçüncü kişiye karş1 actio servi corrupti açllabilirdi ${ }^{47}$.

Beşinci sınıflandırma, ticarî özellikler taşıdığı için ve buna bağlı olarak da, haksız rekabet çerçevesinde değerlendirilebileceği için, bizim açımızdan önem taşımaktadır. Buna göre, bir kölenin kendisine tanınmış olan peculium' ' ${ }^{48}$ kötü yönetmesi ${ }^{49}$, efendisinin hesapların1, ticarî belgelerini bozması ya da değiştirmesi ${ }^{50}$, efendi ile bir sözleşme yapacak olan sözleşmenin karşı tarafının iradesini bozarak veya karıştırarak, sözleşmenin yapılmasını engellemesi ${ }^{51}$ ve son olarak da, kölenin efendisinin hesaplarının,
D. 11, 3, 1, 5; D. 11, 3, 16 .
D. $11,3,1,5$.
D. 11, 3, 1, 5 .
D. $11,3,1,5$.
D. 11, 3, 2

D. 11, 3, 1, 5; Schiller, Trade, s. 841; Böyle durumlarda ilk kölenin efendisi, köleyi yoldan çıkaran üçüncü kişiye karşı dava açabilirdi. Fakat kendisi de, verilmiş olan zarardan ötürü, ikinci kölenin efendisine karş1 sorumlu idi. D. 11, 3,14, 7; İkinci köleyi yoldan çıkaran ilk köle de, noxal sorumluluğun konusunu oluşturduğu için, zarar miktarına göre karşı tarafa teslim edilebilirdi.

D. 11, 3, 2 .

D. 11, 3, 15 .

47 D. 47, 11, 5; Schiller, Trade, s. 841; Böyle durumlarda köleyi yoldan çıkaran üçüncü kişiye karşı açılacak actio servi corrupti'nin yanısıra, onun cezaî sorumluluğu da söz konusu idi. C. Th. 9, 44, 1; C. 1, $25,1$.

48 Jolowicz, H., F./ Nicholas, B.: Historical Introduction to the Study of Roman Law, Cambridge, 1972, s. 90-1; 389-394; Di Marzo, s. 169; Peculium, hakimiyet (potestas) hakkına sahip olan tarafından, hakimiyet altındakine tahsis edilen ve onun yönetimine bırakılan bir miktar para ya da belli bir mal anlamına gelmekteydi.

49 D. 11, 3, 1, 5; Köle, peculium'u, ayrı özel bir malvarlı̆̆ı olarak koruması gerekirken, peculium dahilindeki mallarla, efendisinin malvarlığını karıştırmışsa, peculium'u iyi yönetmediği kabul edilebilirdi.

50 D. 11, 3, 1, 5.

51 D. 11, 3, 11, 1; D. 11, 3, 1, 5. 
meslekî belgelerinin kopyalarını alması ${ }^{52}$ için kışkırtılmasıdır. Kölenin bu şekilde kışkırtılması hem etike aykırı hem de rekabet hukukuna aykırı kabul edilmekteydi ${ }^{53}$.

\section{Actio Servi Corrupti'nin Özellikleri}

Actio servi corrupti, öncelikle praetor hukukunca getirilmiş yani actio in factum $^{54}$ şeklinde bir ceza davası idi $^{55}$. Praetor'lar, diğer in factum şeklindeki davalarda olduğu gibi, actio servi corrupti ile de, ius civile'nin dava hakkı tanımadığı bazı çekişmeli durumlara, dava hakkı sağlamışlardı ${ }^{56}$. $\mathrm{Bu}$ davada, kölesi yoldan çıkartılarak, zarara uğramış olan efendi, davacı (actor), köleyi yoldan çıkaran davalı (reus), sıfatını taşırdı ${ }^{57}$. Söz konusu

52 D. 47, 2, 52, 24; Bu yönde bir kışkırtma yapan kişiye karşı aynı zamanda, actio de dolo açmak da mümkündü.

53 Schiller, Trade, s. 841, Buckland, Slavery, s. 35.

54 De Zulueta, s. 227; Hunter, W. A.: Roman Law in Their Order of a Code, 2. Ed., London, 1895, s. 986; Umur, Notlar, s. 260; Wenger, s. 164; Ius civile davalarının formula'larının intentio kısmına, in ius concepta denirken, praetor davalarının formula'larının intentio kısmı ise, in factum concepta adını almaktaydı. Gai. 4, 45; Ius civile tarafından tanınan bir hak üzerindeki çekişme için yapılan formula'lara, in ius concepta- hakka dayanan denir. Örneğin, bir malın Quirites hukukuna göre bize ait olduğunu veya bize verilmesi yükümlülüğü bulunduğunu, ya da hırsılzlı nedeniyle zararımız olduğunu iddia ettiğimiz durumlarda olduğu gibi.

Gai. 4, 46; "In factum concepta- olaya dayanan dediğimiz diğer bazı formula'larda, intentio kısmı in ius davalarındaki gibi olmayıp, baş tarafında, gerçekleşmiş olan olay açıklanır, daha sonra da, hakime, davalıyı mahkum etmesi ya da beraat ettirmesi için, yetki veren sözler eklenirdi. Praetor'un beyannamesindeki hükme aykırı olarak, efendisini magistra önüne davet eden azatlıya karşı, efendinin kullandığı formula, şu şekildedir; "Recuperatores olsunlar. $\mathrm{Bu}$ efendi, azatlısı tarafindan, praetor'un beyannamesinin aksine, magistra önüne davet edilmişse, ey hakimler, bu azatlıy efendisine onbin sesters ödemeğe mahkum edin, ispatlanamazsa, beraat ettirin".

D. 11, 3, 1; D. 11, 3, 5; D. 11, 3, 16; De Zulueta, s. 299; Actio servi corrupti'ye benzer özellikler taşıyan diğer ceza davaları da, actio furti ve actio quod metus causa in quadruplum idi. Bu davalar, hırsızlık ve ikrah durumlarında açılmaktaydı. Bu davalarda da, köleyi yoldan çıkarma davasında olduğu gibi, zararın iki misli para cezası olarak ödenmekteydi. Ayrıca, bu davaların davalılarından, iusiurandum calumniae yi gerçekleştirmeleri mümkün değildi. Bu, bir çeşit yemin anlamına gelmekteydi. Davada tarafların davayı kötünüyetle yürütmediklerine, yani davayı kazanma konusunda haklı olduklarına inandıklarına ilişkin yemine iusiurandum calumniae denilirdi.

Buckland, Text-Book, s. 679 vd.

Buckland, s. 595; Actio servi corrupti köleyi iyiniyetli zilyet sifatıla elinde bulunduran tarafından veya ona karşı açılamazdı. Umur, Lügat, s. 159; Possessio bonae fidei denilen iyiniyetli zilyetlik, bir mal üzerinde, hem zamanaşımı ile mülkiyetin kazanılması (usucapio) için gereken diğer şartlar olmaksızın, başkasına zarar verilmediği kanısını taşıyarak, hakimiyet gerçekleştirmek, hem de, kazandırıcı zamanaşımı ile mülkiyetin kazanılması için gereken tüm şartlarla birlikte ve aynı kanıyı taşıyarak hakimiyeti gerçekleştirmek anlamına gelmektedir. Ancak, actio utilis servi corrupti biçimindeki davayı, köle üzerinde intifa hakkı olan kimse açabilirdi. Aynı şekilde bu dava, köle üzerinde intifa hakkı sahibi olana karşı da açı1labilirdi. 
davayı açma hakkı, zarara uğramış olan efendinin mirasçılarına geçmekle birlikte, ceza davası özelliği gereğince ${ }^{58}$, bu davanın davalı konumundaki kışkırtan kişinin mirasçılarına karşı açılabilmesi mümkün olmazdı ${ }^{59}$. Dava sonucunda haksız bulunan davalı, davacının uğramış olduğu zararın iki mislini ödemeye mahkum edilirdi ${ }^{60}$. Actio servi corrupti'nin perpetua ${ }^{61}$ dava olma özelliği bulunmaktaydı. Dava sırasında kölenin ölmesi, azat edilmesi ya da bir başkasına verilmesi durumlarında da, dava sona ermiş olmazd1 ${ }^{62}$.

$\mathrm{Bu}$ davada davalının, kölenin zaten kötü olduğunu, yani o kışkırtmasaydı da, dava konusu kötü davranışları gerçekleştireceği şeklinde bir savunması yapması kabul edilemezdi ${ }^{63}$. Actio servi corrupti'de esas sorun, kölenin ne zaman yoldan çıkartılmış olarak kabul edileceğinin saptanmasıyd. Roma hukukunca kabul edilen kurala göre, bir kölenin efendisine ait malı, efendinin rakibinin kışkırtmasıyla çalması durumunda, rakip bu hırsızlıktan dolayı sorumlu tutulurdu. Malın köle tarafından rakibe getirilip getirilmemiş olması da, bu sonucu değiştirmezdi. Söz konusu mal, bir başkasına teslim edilmiş hatta, ona gelmeden köle tarafından yok edilmiş olsa bile, rakip hirsızlıktan dolayı sorumlu tutulurdu ${ }^{64}$.

Üçüncü kişi, köleyi yoldan çıkarmaya çalışarak, efendisini soymasını istemiş, ancak köle, durumu efendisine bildirmiş ve onu soymamıştır.

58 Di Marzo, s. 91; Actio poenales denilen ceza davaları, ius civile tarafindan ya da praetor'lar tarafından tanınmış olan suçlardan birinin işlenmesi durumunda açılan davalardi.

59 D. 11, 3, 8; D. 11, 3, 13 pr.; Buckland, Textbook, s. $684 \mathrm{vd}$.

60 D. 11, 3, 5, 2; Dava sırasında davalı suçunu itiraf etmiş olsa bile, dava sonucunda mahkumiyet, zararın iki katı biçiminde olmaktaydı. D. 11, 3, 9, 2; D. 11, 3, 10; Davalı, bütün zararların iki misline mahkum edilirdi. D. 11, 3, 14, 5; D. 11, 3, 17.

61 D. 11, 3, 5, 3; Di Marzo, s. 97; Roma hukukunda, davalar actiones perpetuae ve actiones temporales şeklinde bir ayrıma da tâbi tutulmaktaydı. Actiones perpetuae daimi dava, actiones temporales ise vadeli, belli bir süreye bağlanmış olan dava anlamına gelmekteydi. Daimi davalar için de, her şekilde belli bir süre sınırlaması bulunmaktaydı. $\mathrm{Bu}$ da otuz yıl şeklindeydi.

D. 11, 3, 5, 4 .

63 D. 11, 3, 1, 4 .

64 D. 11, 3, 10; Schiller, Trade, s. 842; Bu konuya ilişkin olarak akla gelebilecek bir soru, rakibin, kendi eline geçmeyecek ya da kullanmayacağı şeylerin efendisinden alınmasını istemesinde ne yarar olacağıdır. Burada tamamen meslekî kazançlar dahilinde düşünmek doğru olacaktır. Çünkü rakibin efendiyi ticarî olarak zora sokması, kısa vadede kendisine büyük bir şey sağlamasa bile, uzun vadede efendiyi rekabetten çıkararak, rakibin büyük kazançlar sağlamasına yol açmaktadır. Zaten Roma hukuku kaynaklarında konuyla ilgili açıklamalarda genellikle verilen örnekler, rakip için büyük yararlar taşıyan bilgileri içeren, efendiye ait belgeler hakkındadır. D. 47, 2, 52, 24; Eğer bir köle efendisine ait dökümanları kopyalamaya ikna edilmişse, köleyi buna ikna eden kişiye karş1, efendi actio servi corrupti' yi açabilirdi. Rakibin, efendinin ticarî konumu hakkında fikir sahibi olduğu ya da ona ait gizli bilgilere ulaştığı an, zararın meydana geldiği kabul edilirdi. 
Böylece, köleyi yoldan çıkarmaya çalışan üçüncü kişi yakalanmıştır. Gaius'a göre, böyle bir durumda mantıken actio servi corrupti'nin açılması mümkün olmamalıydı ${ }^{65}$. Çünkü, köle yoldan çıkmamış, hırsızlık da yapılmamıştı.

Gai. 3, 198: "Sed et si credat aliquis inutio domino se rem contrectare, domino aiutem uolente id fiat, dicitur furtum non fieri. unde illud quaesitum (et probatum) est: cum Titius seruum meum sollicitanerit, ut quasdam res mihi subriperet et ad eum perferret, et seruus id ad me pertulerit, ego dum, uolo Titium in ipso delicto deprehendere, permiserim seruo quasdam res ad eum perferre, utrim furti a serui corrupti iudicio teneatur Titius mihi, an neutro? responsum neutro eum teneri, furti ideo, quod non inuito me res contrectarit, serui corrupti ideo, quod deterior seruus factus non sit.

Eğer bir kimse, elinde bulunan malı malikinin iradesine aykırı olarak yönettiğini düşünürse, ancak malikin gerçek iradesi, bu idareye uygun ise, artık ortada bir hırsızlık olduğu söylenemez. Buna göre üzerinde tartışılması gereken husus, eğer Titius benim kölemi, bana ait bir şeyi çalması ve söz konusu malı ona getirmesi konusunda kandırırsa, köle bu durumu bana bildirmelidir. Titius'un suçunu ortaya koymak isteyen ben de, kölemin söz konusu malı almasına izin vermeliyim. Böylece Titius'un bu malın çalınmasından $\mathrm{ml}$, yoksa kölenin yoldan çıkarılmasından $\mathrm{m} 1$ sorumlu tutulacağı yoksa hiçbir şeyden sorumlu tutulmayacağ 1 ortaya çıkacaktır. Burada esas olarak Titius, hiçbirşeyden dolayı sorumlu tutulmalıdır. Öncelikle, Titius, hırsızlıktan ötürü sorumlu tutulamaz. Çünkü, mala benim iradem dışında bizzat el süren o, değildir. Köleyi yoldan çıkarmaktan dolayı da sorumlu tutulamaz. Çünkü, köle herhangi bir kötülük yapmamıştır. Malı benim irademe uygun olarak, Titius'a vermiştir”.

Fakat, Iustinianus bunun aksine bir düzenleme yapmışt1 ${ }^{66}$. Buna göre, böyle durumlarda, hem actio furti denilen hırsızlık davasını, hem de actio servi corrupti'yi açmak mümkün olmalıyd.

Iust. Inst. 4, 1, 8: "Sed et si credat aliquis invito domino se rem commodatam sibi contrectare, domino autem volente id fiat, dicitur furtum non fieri. Unde illud quaesitum est, cum Titius servum Maevii sollicitaverit, ut quasdam res domino subriperet et ad eum perferret, et servus id ad Maevium pertulerit, Maevius, dum vult Titum in ipso delicto deprehendere, permisit servo quasdam res ad eum perferre, utrum furti an servi corrupti iudicio teneatur Ttitius, an neutro? Et cum nobis super hac dubitatione suggestum est et antiquorum prudentium super hoc altercationes perspeximus, quibusdam neque furti neque servi corrupti actionem praestantibus, quisdam furti

\footnotetext{
65 Gai. 3, 198.
}

66 Iust. Inst. 4, 1, 8. 
tantummodo: nos huismodi calliditati obviam euntes per nostram decisionem sanximus non solum furti actionem sed etiam servi corrupti contra eum dari: licet enim is servus deterior a sollicitatore minime factus est et ideo non concurrant regulae, quae servi corrupti actionem introductum est, ut sit ei poenalis actio impunitate et in alium servum, qui possit corrumpi, tale facinus a quibusdam perpetretur.

Hatta bir kimse, ariyet aldığı şeyi malikin iradesine aykırı kullandığını sandığı halde, kullanma malikin iradesine uygunsa, yine furtum olmadığı söylenir. Bundan şöyle bir sorun çıkar: Titius, Maevius'un kölesini, malikinden bir şeyler çalıp kendisine getirmesi konusunda teşvik etse ve köle bunu maliki Maevius'a ihbar etse; Maevius da, Titius'u, bu haksız fiil üzerinde yakalamak istediği için, kölesinin bu şeyleri çalmasına izin verse, Titius (hırsızlık) furtum davasından mı, veya köleyi yoldan çıkarmak davasından mı (actio servi corrupti) sorumlu olacak, yoksa hiç birisinden sorumlu olmayacak mı? $\mathrm{Bu}$ tereddütün kaldırılması bize sunulduğundan, eski hukukçuların ise bu konuda, kimileri ne hırsızlık davasını ne de köleyi yoldan çıkarmak davasını tanıyarak, kimileri de yalnızca hırsızlık davasını tanıyarak, çeşitli tartışmalara giriştiklerini gördügümüzden ve bu çeşit gereksiz incelikleri önlemek istediğimizden, bu halde, hem hırsızlık davasının hem de köleyi yoldan çıkarmak davasının açılabileceğine karar verdik: Gerçekten burada köle, üçüncü kişi tarafından yoldan çıkarılmamış olmasına ve bu yüzden actio servi corrupti'nin unsurlarının bulunmamasına rağmen, köleyi yoldan çıkarma amacı açık olduğundan, bu kölenin yoldan çıkarılmış olduğu varsayılarak, üçüncü kişinin cezalandırılması yönündeki davayı kabul ettik; bu suretle söz konusu iradeyi cezasız bırakarak, yoldan çıkarılması daha kolay olan köleler üzerinde başkalarının aynı fiili gerçekleştirmeleri olasılığı ortadan kalkmış oldu"67.

Son olarak, bu davada efendinin uğramış olduğu zararın tespit edilmesi de gerekmekteydi. Bu tespit sırasında, kölenin değerinde oluşan azalmalar $^{68}$, kölenin haksız davranışları nedeniyle efendinin uğramış olduğu kayıplar ve meslekî zararlar ${ }^{69}$ değerlendirmeye alınmaktaydı. Ayrıca, bu değerlendirme açısından kölenin yoldan çıkarılarak gerçekleştirdiği faaliyetin devam etme süresi ve efendinin kaybettiği ticarî itibar ve kâr olanakları da önem taşımaktayd ${ }^{70}$. Davalının tazmin edeceği zararlar, efendinin hem doğrudan hem de dolaylı olarak uğradığı zararları kapsamaktayd ${ }^{71}$.

Bu konuya ilişkin olarak C. 6, 2, 20'de de benzer yönde açıklamalar yer almaktadır.

D. $11,3,9,3$; D. 11, 3, 14, 8 .

D. 11, 3, 14, 6 .

D. 11, 3, 6; D. 11, 3, 14, 5; D. 47, 11, 5 .

D. 11, 3, 9, 3 . 


\section{Actio Servi Corrupti'nin Roma Haksız Rekabet Hukukundaki} Yeri

Actio servi corrupti ${ }^{6}$ yi Roma hukukunun uygulandığı dönemi de düşünerek değerlendirğimizde, haksız rekabet hukuku açısından çok büyük yenilikler getirdiği sonucuna varabiliriz. Öncelikle efendinin actio servi corrupti'yi aleyhine açtığı davalı konumundaki, köleyi yoldan çıkaran üçüncü kişinin, kölenin efendisinin ticaret alanındaki rakibi olarak kabul edilmesi gerekirdi ${ }^{72}$. Çünkü, rakibe ait ödenmemiş borçların ispatını olanaksız hale getirecek şekilde, efendiye ait ticarî tutanakların değiştirilmesi, rakibe ait borçların bu tutanaklardan çıkarılması, müşteri listesinin yok edilmesi, efendinin meslekî kazançlarını bir şekilde zarara uğratacak şekilde efendiye ait kayıtların silinmesi ya da değiştirilmesi ${ }^{73}$, köleyi yoldan çıkartan rakibinin çıkarlarına katkıda bulunmaktayd ${ }^{74}$. Bir kimsenin başkalarına ait ticarî belgeleri, onları kullanmayacak olduktan sonra, çalmak istemesinde ve bunları çalması için, bir çalışanı kışkırtmaya kalkmasında, hiçbir amaç bulunmamaktayd ${ }^{75}$.

Kölelerin kiralanmaları, ödünç verilmeleri ya da üzerlerinde intifa hakk1 kurulması, Roma hukukunda oldukça sık rastlanılan bir durumdu ${ }^{76}$. Kölenin bu biçimde çalıştırılması, efendinin köleyi kiralayıp, ödünç alıp ya da üzerinde intifa hakk1 sahibi olup, onu kışkırtana karşı actio servi corrupti'yi açmasına engel oluşturmazdı. Doğal olarak, bu çeşit hukukî ilişkilerde, kölenin yoldan çıkarılma ve efendisine ait meslekî sırları açığa vurma riski oldukça yüksekti. Efendi, kölesini verdiği rakibinin köleyi kışkırtması üzerine, zarara uğramışsa, söz konusu kişi ile aralarındaki hukukî ilişkiden bağımsız olarak, ona karşı actio servi corrupti'yi açarak, zararının tazminini isteyebilirdi. Böyle bir hukukî ilişki çerçevesinde köleyi efendisi yoldan çıkarmış ve köleyi belli bir süre için kullanan rakibinin meslekî sırlarını elde etmişse, ne olacaktır? Bu durumda, köleyi elinde bulunduranın

72 Aubert, J.: Business Managers in Ancient Rome, A Social and Economic Study of Institores,. 200 B.C. A. D. 250, Leiden, 1994, s. 63; Aslında böyle bir saptama bile, Roma hukuku açısından önemli bir adımdı. Hatta bu durum, köleyi yoldan çıkaranın, sırf efendiye duyduğu kin nedeniyle hareket etmişse ve bu yüzden doğrudan bir kazanç elde etmemiş olsa bile geçerliydi.

73 D. 11, 3, 10; Yoldan çıkarılmış köle tarafından, efendisine ait meslekî belgelerini bir yabancıya teslim edilmiş olmasından söz edilmektedir.

76 Buckland, Slavery, s. 265 vd., 356 vd. Roma hukukunda commodatum, depositum, locatio conductio, ususfructus ve precarium sözleşmelerine dayanarak, bir kölenin bir başkasının hizmetine bırakılması mümkündü. Hatta kefalet, vedia gibi hukukî ilişkilerde, kölenin karşı tarafa bırakılması, ücretsiz olarak gerçekleştirilmekteydi. Bu şekilde yiyeyecek ve barındırma masrafları azaltılmış olmaktaydı. 
efendiye karş1 actio servi corrupti'yi açabileceği hususunda kesin bilgimiz bulunmamaktadır. Ancak, intifa hakkına ilişkin olarak özel bir düzenleme bulunmaktayd ${ }^{77}$. Buna göre, köle üzerinde intifa hakk1 sahibi, kölenin efendisi tarafından kışkırtılıp, yoldan çıkarılması durumunda, efendiye karşı, actio utilis servi corrupti denilen davay1 açabilirdi ${ }^{78}$. Ayn1 durum, üçüncü kişiler açısından da geçerlidir. Yani, üzerinde intifa hakkı kurulmuş olan köleyi efendi değil de, üçüncü kişi yoldan çıkartmışsa, yine intifa hakkı sahibi, actio utilis servi corrupti'ye başvurabilirdi ${ }^{79}$.

77 D. 11, 3, 9, 1; D. 11, 3, 14, 3; Karagöz-Çokyaşar, s. 186-7; Burada, intifa hakk1 ile mülkiyet arasında bir bağlantı kurulmuştur. İntifa hakkı da, bir aynî hak olması ve sahibine söz konusu malı kullanma ve semerelerinden yararlanma hakkı sağlaması nedeniyle, efendinin açabileceği actio servi corrupti, actio utilis servi corrupti şekliyle intifa hakkı sahibine de tanınmıştır.

78 Umur, Notlar, s. 260; Praetor'lar, bazı durumlarda, ius civile'ce tanınmış bir dava formula'sını, ius civile tarafından korunmamış bir olaya uygulayacak şekilde değiştirerek, kıyas yoluyla uygulama alanını genişletmekteydiler. Bu şekilde ortaya çıkan davalara da, actio utilis denilmekteydi.

79 Karagöz-Çokyaşar, s. 187; Actio utilis servi corrupti’nin açılabilmesi için, üzerinde intifa hakkı kurulmuş olan kölenin, ya bizzat efendi tarafindan daha kötü yapılması, ya da üçüncü kişi tarafından zorla alınması veya kötü yola sevkedilmesi gerekmekteydi. Doğal olarak kölenin kötü huylar edinmesi, onun değerini azaltmaktaydı.

Ancak, yapılan bu açıklamalar doğrultusunda, actio utilis servi corrupti'nin haksız rekabet hukuku ile tam olarak ilişkin olduğunu söyleyebilmek de kolay olmayacaktır. Burada haksız rekabet açısından ticarî bir amaç bulunup bulunmadığı da bilinmemektedir. Yani, actio utilis servi corrupti'nin, haksı rekabeti engelleme amac1 olduğunu kesin olarak kabul etmek mümkün değildir. İntifa hakkı sahibine bu şekilde bir dava hakkı tanıma, esas olarak, intifa hakkı sahibine sağlanan hizmetin hiçbir şekilde bozulmamasını garanti almaya yönelik, daha güçlü bir tedbir şeklinde idi. Ancak, intifa hakkı ile sağlanan hizmetin ticarî bir hizmet olup olmadığı önem taşımamaktaydı. Köleyi ödünç almış ya da kiralamış olanların durumunun, intifa hakkı sahibi ile kıyaslanabilmesi de oldukça tartışmalıdır. Köleyi bir şahsî hak doğuran sözleşme çervesinde kullananların durumu, intifa hakkı sahibine benzetilirse, bunların da, köleyi yoldan çıkaran efendi ya da üçüncü kişilere karşı actio servi corrupti'yi açabilecekleri kabul edilebilir. Esas olarak, her iki durumda da, korunan amaç aynıdır. Oysa, intifa hakkına getirilmiş özel durumun, şahsî bir hak doğuran kira ya da ödünç ilişkilerinin niteliğine uymayacağı da düşünülebilir. Çünkü intifa hakkı sahibinin, malikten daha dar kapsamlı olsa bile, yine de köle üzerinde bir aynî hakkı bulunmaktaydı. Üstelik Roma hukuku kaynaklarından edinilen bilgiler doğrultusunda, daha once de belirtildiği gibi, actio servi corrupti'nin köle üzerinde şahsî bir hakkı bulunan kişi tarafından, kölenin gerçek efendisine karşı açılması, pek rastlanılan bir durum değildi. Sonuçta actio servi corrupti, yalnızca haksız rekabeti önleme amacı taşıyan bir dava değildi. Ancak, şunu da unutmamak gerekir ki, Roma hukukunda, efendi yoldan çıkmış kölenin verdiği zararlardan ötürü, köleyi kiralamış ya da ödünç almış olana karşı sorumlu tutulurdu. Doğal olarak, konusu bir kölenin kiralanması ya da ödünç verilmesi olan bir sözleşmenin tarafları, bu sözleşmenin hukukî niteliği gereğince, birbirlerine karşı sorumlu olmaya devam ederlerdi. Genellikle, taraflar kölenin ödünç verilmesi ya da kiraya verilmesine ilişsin sözleşmeyi yaparlerken, kölenin yoldan çıkartılması durumunda, efendinin ne oranda sorumlu tutulacağına ilişkin koruyucu hükümleri de düzenlemekteydiler (Schiller, Trade, s. 844). 
Actio servi corrupti ilk olarak ortağa çıktığında, ticarî bir amacı bulunmasa bile zamanla, bu davanın, haksız rekabeti önleme amacı da gütmeye başlamıştı. Bu amacı destekleyen bir diğer durum ise, bir kimsenin işletmesinde yönetici olarak çalışanın yoldan çıkarılması durumunda, yoldan çıkartmayı teşvik eden rakibe daha sert cezaî yaptırımların uygulanmasıyd ${ }^{80}$. Doğal olarak, bir işyerinin yöneticinin, o işyeri hakkında aynı işyerinde çalışan işçilerden, daha fazla bilgiye sahip olması ya da çok önemli belgelere daha kolay ulaşabilecek olması, böyle bir uygulamayı gerekli kılmıştı. Aynı şekilde, actio servi corrupti 'nin ceza davası olma özelliğinin, Roma hukukunun ilerleyen zamanlarında kaybolması da, söz konusu davanın haksız rekabeti önleme özelliğini kuvvetlendirmekteydi ${ }^{81}$. Çünkü böylece, davalı yani cezalandırılması düşünülen kişiden çok, zarar gören efendi ve onun uğramış olduğu kayıplar önem kazanmıştı. Yani, davanın amacı, esas olarak yoldan çıkartanı cezalandırmaktan çok, yoldan çıkartma yüzünden zarara uğrayanın bu zararlarının tazmin edilmesi haline gelmiştir $^{82}$. Buna bağlı olarak da, actio servi corrupti kölenin ölmesinden ya da çalınan malın yeniden elde edilmesinden sonra da açılabilir bir dava olarak kabul edilmişti ${ }^{83}$.

Zamanla bu dava ile korunan yararlar, yalnızca köleler tarafindan zarara uğratılmasında değil, hür kişilerce ya da aile evlâtlarınca zarara uğratılması durumlarında da korunmuştu ${ }^{84}$. Yani, işçinin yoldan çıkartılarak, işverenini zarara uğratması halinde, kışkırtıcının cezalandırılması gerektiği Roma hukukunda kabul edilmişti ${ }^{85}$.

\section{Sonuc}

Actio servi corrupti ${ }^{6}$ ye ilişkin bütün bu açıklamalar, çoğu alanlarda günümüz hukukunun temelini oluşturan Roma hukukunun, haksız rekabet hukukuna ilişkin de önemli adımlar attığını ve kendi dönemi açısından büyük yenilikler getirdiğini açıkça göstermektedir. Her ne kadar, Roma toplumunda iş hayatı fazla gelişmemiş olsa da, rekabetin engellenmesi bu dönemde bile hoş karşılanmamaktaydı. Bu yüzden Klâsik hukuk döneminde, devletin yalnızca devlet hazinesi ile ilgilendiği ve idarî alanda sınırlı sayıda

\footnotetext{
D. 1, 18, 21.

D. 11, 3, 5, 4 .

Buckland, Slavery, s. 34; D. 11, 3, 8; Bu davayı, efendinin mirasçıları da açabilirler.

D. 11, 3, 12; Schiller, Trade, s. 845.

D. 11, 3, 5, 1; Özgür bir kişiyi, rakibe ait bir köle zannederek yoldan çıkaran kimseyi de, bu haksız davranışdan ötürü sorumlu tutmak mümkün olmaktaydı.

85 Rostovtsev, s. 163, 515, 538; Bu şekildeki genişlemenin zaman alması, Roma toplumunda işlerin genellikle köleler aracıllı̆ıyla gerçekleştirilmesi ile açıklanabilir. D. 11, 3, 14, 1; Roma hukukçuları tarafından açıklandığı üzere, bir aile evlâdının kandırılarak yoldan çıkarılması durumunda, aile evlâdının hakimiyeti altında olduğu aile babasının, kışkırtana karşı, actio utilis servi corrupti' yi açması mümkün kabul edilmişti.
} 
faaliyetleri gerçekleştirdiğini söylemek tam olarak gerçeği yansıtmaz. Çünkü, bu dönemde de haksız rekabeti önlemek başta olmak üzere, ticareti koruyucu birtakım önlemler alınmıştı. Öncelikle iş hayatında etkin rolleri olan kölelerin çeşitli şekillerde kandırılarak, efendilerinin meslekî faaliyetlerine zarar verecek şekilde davranmaları sağlanmışsa, bu şekilde köleyi yoldan çıkartanlar, kölenin efendisinin uğradığı zararın iki mislini, ceza olarak ödemek zorunda kalıyorlardı. Praetor'lar tarafindan alınmış bu önlemler, hem rekabeti koruyor, hem de rekabeti engelleyici faaliyetlerde bulunanları ağır bir biçimde cezalandırıyordu. 


\section{KAYNAKÇA}

Aubert, J.: Business Managers in Ancient Rome, A Social and Economic Study of Institores, 200 B.C.- A.D. 250, Leiden, 1994.

Berger, A.: Encyclopedic Dictionary of Roman Law, Philadelphia, 1968.

Barrow, R. H.: The Romans, 2. ed. Cambridge, 1990.

Barrow, R. H.: Slavery in the Roman Empire, with Twelve illustrations, London, 1928.

Buckland, W. W.: A Text-Book of Roman Law from Augustus to Justinian, 2. Ed., Cambridge, 1932.

Buckland, W, W.: Elementary Principles of the Roman Private Law, Cambridge, 1912.

Buckland, W. W.: Roman Law of Slavery, the Condition of the Slave in Private Law from Augustus to Justinian, Cambridge, 1908.

Carcopino, J.: Daily Life in Ancient Rome, the People and the City at the Height of the Empire, Trans. from french by Lorimer, London, 1941.

Charlesworth, M. P.: Trade-Routes and Commerce of the Roman Empire, Cambridge, 1926.

Clark, R. P. L.: Roman Private Law, Oxford, 1926.

Costa, E.: Storia delle Fonti del Diritto Romano, Torino 1909.

Daube, D.: Forms of Legislation, Oxford, 1956.

Di Marzo, S. (Çev. Z. Umur): Roma Hukuku, 5. Bası, İstanbul, 1954.

De Martino, F.: Storia Economica di Roma Antica, V. I, Firenze, 1979.

De Zulueta, F.: The Institutes of Gaius, Part II, Oxford, 1953.

Duncan-Jones, R.: The Economy of Roman Empire, 2. ed., Cambridge, 1982.

Finley, M. I.: The Ancient Economy, updated, California, 1999.

Frank, T.: An Economic Survey of Ancient Rome, New York, 1959.

Frank, T.: A History of Rome, New York, 1950.

Greenidge, A. H. J.: Infamia, Its Place in Roman Public and Private Law, Oxford 1894.

Heichelheim, F.: An Ancient Economic History, V. I, Leiden, 1958 V. II, 1964, V. III, 1970.

Hunter, W. A.: Roman Law in Their Order of a Code, 2. Ed., London, 1895.

Jolowicz, H. F./ Nicholas, B.: Historical Introduction to the Study of Roman Law, Cambridge, 1972.

Jones, A. H. M.: The Later Roman Empire, 284, 602; A Social, Economic and Administrative Survey, V. I-II, Oxford, 1964.

Jones, A. H. M.: The Roman Economy, Studies in Ancient Economics and Administrative History, Oxford, 1974.

Karadeniz, Ö.: Iustinianus Zamanına Kadar Roma’da İş İlişkileri, Ankara, 1976. 
Karadeniz-Çelebican, Ö.: Roma Hukuku, Tarihi Giriş- Kaynaklar- Genel Kavramlar- Kişiler Hukuku- Hakların Korunması, Yeni Medeni Kanun'a Uyarlanmış 8. basım, Ankara, 2003.

Karagöz-Çokyaşar, H.: İntifa Hakkının Roma Hukukundaki Gelişimi ve Türk Hukukuna Etkisi, İstanbul, 2003.

Küçükgüngör, E.: Roma Hukukunda İntifa Hakkı (Ususfructus), Ankara, 1998.

MacCormack, G.: "The Liability of Mandatary", Rassegna di Diritto Romano (Labeo), 18, 1972.

Pacchioni, G.: Corso di Diritto Romano, 2. V., Torino, 1910.

Provera, G.: "Visuali Romanistiche in Tema di Patti di non Concurrenza, Annali Camerino, V. 31, 1965.

Rado, T.: Roma Hukuku Dersleri, Borçlar Hukuku, İstanbul, 2001.

Roby, H. J.: Roman Private Law in the Times of Cicero and of the Antonines, V. I, Cambridge, 1902.

Rostovtzeff, M. I.: The Social and Economic History of the Roman Empire, Rep. From 2. ed., V. I-II, Oxford, 1966.

Ruggiero, C. P.: Stato Civile ed il Diritto Internazionale Privato, Padova, 1992.

Schiller, A. A.: Roman Law, Mechanisms of Development, Mouton, 1978.

Schiller, A. A.: "Trade Secrets and the Roman Law; the Actio Servi Corrupti", Colombia Law Review, V. 30, 1930.

Schechter, F. I.: The Historical Foundation of the Law Relating to Trade-Marks, New York, 1925.

Schulz, F.: Classical Roman Law, Reprint of the Ed. 1951, Enlarged by a Preface Scientia, Aalen, 1992.

Tahiroğlu, B.: Roma Hukukunda Iniuria, İstanbul, 1969.

Tengström, E.: Bread for the People: Studies of the Corn Supply of Ancient Rome, Oxford, 1980.

Umur, Z.: Roma Hukuku Ders Notları, 3. Baskı, İstanbul, 1999.

Umur, Z.: Roma Hukuku Lügatı, İstanbul 1975.

Villey, M.: Roma Hukuku Güncelliği, Türkçesi Tahiroğlu, 7. basımdan, İstanbul, 2000.

Wacke, A.: "Freedom of Contract and Restraint of Trade Clauses in Roman and Modern Law", Law and History Review, V. 11, N. 1, Spring 1993.

Wenger, L.: Institutes of the Roman Law of the Civil Procedure, Transl. by Fisk, New York, 1949. 